\title{
Awareness of the right to Argentine Sign Language interpretation services among pediatricians practicing in the Autonomous City of Buenos Aires
}

\author{
Lucas A. Walz ${ }^{a}$,Adrián M. Cutri, M.D. ${ }^{b}$, Fernando A. Torres, M.D. ', Prof. Claudio C. Riquelmed, \\ Prof. Verónica Gatto Bellorac and Fernando C. Ferrero, M.D. ${ }^{c}$
}

\begin{abstract}
Introduction. Barriers in communication between physicians and Deaf or hard of hearing people may be risk factors for health. The services of a professional Argentine Sign Language interpreter (PASLI), by virtue of Act No. 26378, may mitigate this.

Objective. To estimate the proportion of pediatricians who have knowledge of Act No. 26378 and whether this is associated with the recommendation of a PASLI.

Population and methods. Cross-sectional study with a selfadministered electronic questionnaire among pediatricians members of the Sociedad Argentina de Pediatría who practiced in the Autonomous City of Buenos Aires (CABA).

Results. A total of 381 surveys were assessed. Of these, $15.1 \%$ knew the Act, and this was associated with the recommendation of a PASLI (OR: $3.7 ; 95 \%$ CI: 1.1-12.9; $p<0.05$ ).

Conclusions. The proportion of pediatricians working in CABA who knew the Act was $15.1 \%$. This was significantly associated with the recommendation of a PASLI.

Key words: right to health, deafness, sign language.

http: / / dx.doi.org/10.5546/ aap.2021.eng.123
\end{abstract}

To cite: Walz LA, Cutri AM, Torres FA, Riquelme CC, et al. Awareness of the right to Argentine Sign Language interpretation services among pediatricians practicing in the Autonomous City of Buenos Aires. Arch Argent Pediatr 2021;119(2):123-128.

a. Yale University.

b. Special Education School No. 7 "Julia Ofelia Cubilla," Resistencia, Chaco, Argentina.

c. Hospital General de Niños "Pedro de Elizalde," Autonomous City of Buenos Aires, Argentina.

d. Private Education Unit No. 172 "Deolindo Felipe Bittel," Resistencia, Chaco, Argentina.

E-mail address:

Adrián M. Cutri, M.D.: adriancutri@gmail.com

Funding: This study was carried out as part of a fellowship system of Yale University, Gary Stein Summer Fellowship, Yale College Fellowships for Research in Global Health Studies, Steven Clark Senior Essay Travel Grant.

Conflict of interest: None.

Received: 5-28-2020

Accepted: 10-6-2020

\section{INTRODUCTION}

Hearing loss is one of the most prevalent disabilities, ${ }^{1}$ affecting more than 466 million people around the world. ${ }^{2}$ According to the National Ministry of Health of Argentina, hearing disability accounts for $18 \%$ of disabilities at a national level. ${ }^{3}$ In our country, many Deaf and hard of hearing $(\mathrm{DHH})$ individuals use Argentine Sign Language (ASL) to communicate with other people.

Barriers in communication are a risk factor for the health of DHH individuals. Studies done in the United Kingdom demonstrated that they have a higher risk for asthma, hypertension, obesity, and depression. ${ }^{4}$ In addition, they are more likely to perceive that their medical needs are not met. ${ }^{5}$ Although there may be underlying biological reasons, an unequal access to health care services may account for such perception. ${ }^{6}$

It is more likely that $\mathrm{DHH}$ individuals may have difficulties to communicate with, understand, and feel comfortable with their health care providers. In addition, an ineffective communication between physicians and DHH individuals is a limitation to health care. ${ }^{7}$ The services of a professional interpreter that can speak using sign language may mitigate such limitations.

Argentina approved the Convention on the Rights of Persons with Disabilities (Act No. 26378), which subsequently gained constitutional status (Act No. 27044), thus recognizing the rights of people with disabilities. ${ }^{8}$ This regulation stipulates that a professional ASL interpreter (PASLI) should be available, at no charge, to facilitate DHH individuals access to public institutions. In addition, the Convention on the Rights of the Child (Act No. 23849) emphasizes the State's obligations to provide adequate assistance to parents in the performance of their child rearing responsibilities. ${ }^{9}$ The absence of a PASLI during medical consultations implies the violation of the rights of $\mathrm{DHH}$ individuals and of their children.

A questionnaire administered to $\mathrm{DHH}$ parents in the Autonomous City of Buenos Aires (CABA) 
and the province of Chaco revealed that $15.4 \%$ of them had counted with the presence of a PASLI during a medical consultation and that none had obtained such service from the State. ${ }^{10}$ Exploring whether physicians have knowledge of Act No. 26378 and whether they provide information about the right to have a PASLI may be useful to warrant the rights of $\mathrm{DHH}$ individuals.

\section{OBJECTIVE}

To estimate the proportion of pediatricians in CABA who have knowledge of Act No. 26378 and recommend the presence of a PASLI. To explore whether knowledge of Act No. 26378 is associated with the recommendation of a PASLI.

\section{MATERIAL AND METHOD}

This was a descriptive, cross-sectional study with a self-administered, semi-structured, online questionnaire completed between 10-04-2019 and 10-31-2019, using SurveyMonkey ${ }^{\mathrm{TM} 11}$ (see Annex). Pediatricians who were members of the Sociedad Argentina de Pediatría (SAP) and practiced in CABA were included. The primary outcome variable was having knowledge of Act No. 26378 (yes or no).
For the second objective, exploring whether knowledge of the Act was associated with the recommendation of a PASLI, the first variable was used as a predictive outcome measure and the second one, as an outcome variable. Age, years of medical practice, sex, work setting, and experience with $\mathrm{DHH}$ individuals were controlled for (see Annex).

The study was approved by the Research Ethics Committee of Hospital General de Niños "Pedro de Elizalde" and the Human Subjects Committee of the Institutional Review Board of Yale University. In addition, it was supported by the Subcommittee on the Rights of the Child and approved by the Steering Committee of the SAP to use its e-mail address database to send the survey.

There was no validated survey, so it was necessary to develop one. For validation, cognitive interviews were performed with 11 physicians from a children's hospital who did not take part in the online survey afterwards. ${ }^{12}$

The $\chi^{2}$ test was used to explore the association between having knowledge of Act No. 26378 and potential predictors. Significance level $=p<0.05$. The analysis was done with the SPSS 23.0 software.

TABLE 1. Description of the population of pediatricians who completed the survey about Argentine Sign Language

\begin{tabular}{|c|c|c|}
\hline Outcome measure & N (381) & Value $^{a}$ \\
\hline Age & & $45.2 \pm 12.6$ \\
\hline Years of pediatric practice & & $19.3 \pm 13.5$ \\
\hline Sex (female/male $)$ & & $307 / 74$ \\
\hline \multicolumn{3}{|l|}{ Place of work } \\
\hline Private & 103 & $27.1(22.9-31.8)$ \\
\hline Public & 254 & $66.6(61.7-71.1)$ \\
\hline Trade union health insurance & 24 & $6.3(4.3-9.2)$ \\
\hline Have knowledge of Act No. 26378 & $50 / 331$ & $15.1(11.7-19.4)$ \\
\hline Have seen DHH individuals ${ }^{\mathrm{b}}$ & $335 / 381$ & $87.9(84.3-90.1)$ \\
\hline Can speak ASL correctly & $15 / 328$ & $4.6(2.8-7.4)$ \\
\hline \multicolumn{3}{|l|}{ During a visit with a DHH individualc ${ }^{c}$} \\
\hline Rely on lip reading & $265 / 322$ & $82.3(77.8-86.1)$ \\
\hline Use written language & $165 / 322$ & $51.2(45.8-56.7)$ \\
\hline Use ASL & $42 / 285$ & $14.7(11.1-19.3)$ \\
\hline Have a PASLI available & $16 / 322$ & $5.0(3.1-7.9)$ \\
\hline Have a non-professional interpreter available & $149 / 322$ & $46.3(40.9-51.7)$ \\
\hline Recommend a PASLI when there is no interpreter available & $62 / 314$ & $19.7(15.7-24.5)$ \\
\hline Recommend a PASLI when there is a non-professional interpreter available & $15 / 119$ & $12.6(7.8-19.8)$ \\
\hline Are not aware of the PASLI profession & $101 / 256$ & $39.5(33.7-45.6)$ \\
\hline Do not know how to contact a PASLI & $146 / 256$ & $57.0(50.9-63.0)$ \\
\hline Had trouble contacting a PASLI & $24 / 272$ & $8.8(6.1-12.8)$ \\
\hline
\end{tabular}

${ }^{a}$ Mean \pm standard deviation (continuous outcome measures) and $\%$ with $95 \%$ confidence interval (categorical outcome measures).

${ }^{\mathrm{b}}$ Deaf and hard of hearing (DHH) individuals.

c This includes responders who indicated "frequently or always."

ASL: Argentine Sign Language; PASLI: professional Argentine Sign Language interpreter. 


\section{RESULTS}

A total of 16140 SAP members across Argentina were contacted; 1094 surveys were completed. Of these, 381 were from pediatricians who worked in $\mathrm{CABA}$, although not everyone answered every question in the survey. Table 1 shows the information about analyzed outcome measures.

Among survey respondents, 50 out of 331 (15.1\%; $95 \%$ confidence interval [IC]: 11.7-19.4) stated that they had knowledge of Act No. 26378. Having knowledge of the Act was associated with recommending a PASLI (odds ratio [OR]: 3.7; $95 \%$ CI: $1.1-12.9 ; p<0.05)$, reporting problems to get one (OR: 7.3; $95 \%$ CI: 2.9-18.3; $p<0.01)$, and being more familiar with ASL (OR: 5.5; $95 \%$ CI: 2.7-11.0; $p<0.001$ ) (Table 2).

In addition, $87.9 \%$ of survey respondents stated that they had seen at least one $\mathrm{DHH}$ patient or parent. In $92.5 \%$ of cases where there was an interpreter present during the visit, they were not professionals. Furthermore, 14/ 25 who requested a PASLI had trouble getting one (Table 1).

\section{DISCUSSION}

Our study revealed that $15.1 \%$ of survey respondents (pediatricians members of the SAP who practiced in CABA) had knowledge of Act No. 26378 and that this was associated with the recommendation of a PASLI. It is worth noting that, just as a high percentage of physicians did not know the Act and did not recommend a PASLI, according to local data, less than half of DHH individuals knew their right to have a PASLI present during their children's medical consultations. ${ }^{10}$

It has been observed that more than $95 \%$ of surveyed health care providers did not speak ASL. This, in addition to not using a PASLI, may result in embarrassing situations and predispose DHH individuals to answer "yes to everything," which would have a negative effect on patientdoctor understanding and compromise the outcomes of the medical consultation.

There was an association between having knowledge of Act No. 26378 and the

TABLE 2. Description of analyzed outcome measures based on knowledge of Act No. $26378^{a}$

\begin{tabular}{|c|c|c|c|c|}
\hline \multirow[t]{2}{*}{ Characteristics } & \multicolumn{2}{|c|}{ Knowledge of Act No. 26378} & \multirow[b]{2}{*}{ OR $(95 \% \mathrm{CI})$} & \multirow[b]{2}{*}{$p$} \\
\hline & Yes $(N=50)$ & No $(N=331)$ & & \\
\hline Age $^{a}$ & $48.6 \pm 12.4$ & $44.4 \pm 12.6$ & & 0.06 \\
\hline Years of practice ${ }^{a}$ & $23.1 \pm 13.2$ & $19.1 \pm 13.4$ & & 0.06 \\
\hline Sex (male/female) & $15 / 35$ & $50 / 229$ & $1.9(0.9-3.8)$ & 0.07 \\
\hline $\begin{array}{l}\text { Place of work } \\
\text { Private } \\
\text { Public } \\
\text { Trade union health insurance }\end{array}$ & $\begin{array}{c}9(18.4 \%) \\
37(75.5 \%) \\
3(6.1 \%)\end{array}$ & $\begin{array}{c}81(28.8 \%) \\
183(65.1 \%) \\
17(6.1 \%)\end{array}$ & & \\
\hline Have seen a DHH individual ${ }^{\mathrm{b}}$ (yes/no) & $42 / 8$ & $245 / 36$ & $0.7(0.3-1.7)$ & 0.7 \\
\hline Can speak ASL correctly (yes/no) & $8 / 7$ & $42 / 271$ & $7.3(2.5-21.4)$ & $<0.01$ \\
\hline $\begin{array}{l}\text { During a visit with a DHH individual } \\
\text { Rely on lip reading }(\mathrm{a} / \mathrm{r} \mathrm{n})^{\mathrm{c}} \\
\text { Use written language }(\mathrm{a} \mathrm{f} / \mathrm{r} \mathrm{n}) \\
\text { Use ASL }(\mathrm{a} \mathrm{f} / \mathrm{r} \mathrm{n}) \\
\text { Have a PASLI available }(\mathrm{a} \mathrm{f} / \mathrm{r} \mathrm{n}) \\
\text { Have a non-professional interpreter available }(\mathrm{a} \mathrm{f} / \mathrm{r} \mathrm{n}) \\
\text { Recommend a PASLI when there is no interpreter } \\
\text { available }(\mathrm{a} \mathrm{f} / \mathrm{r} \mathrm{n})\end{array}$ & $\begin{array}{c}(32 / 10) \\
23 / 19 \\
6 / 36 \\
6 / 36 \\
16 / 26 \\
20 / 22\end{array}$ & $\begin{array}{c}(201 / 42) \\
130 / 113 \\
7 / 236 \\
8 / 235 \\
117 / 126 \\
35 / 210\end{array}$ & $\begin{array}{c}0.7(0.3-1.4) \\
1.1(0.5-2.2) \\
5.6(1.7-17.6) \\
4.9(1.6-14.9) \\
0.6(0.4-1.3) \\
5.4(2.7-11.1)\end{array}$ & $\begin{aligned} & 0.4 \\
& 0.9 \\
< & 0.01 \\
< & 0.01 \\
& 0.2 \\
< & 0.01\end{aligned}$ \\
\hline $\begin{array}{l}\text { Recommend a PASLI when there is a } \\
\text { non-professional interpreter available (a } \mathrm{f} / \mathrm{r} \mathrm{n})\end{array}$ & $5 / 12$ & $9 / 80$ & $3.7(1.1-12.9)$ & 0.04 \\
\hline Are aware of the PASLI profession (yes/no) & $23 / 6$ & $127 / 91$ & $3.6(1.2-11.3)$ & 0.04 \\
\hline Know how to contact a PASLI (yes/no) & $16 / 13$ & $91 / 127$ & $1.7(0.8-3.7)$ & 0.2 \\
\hline Had trouble contacting a PASLI (yes/no) & $11 / 30$ & $11 / 220$ & $7.3(2.9-18.3)$ & $<0.01$ \\
\hline
\end{tabular}

a Average \pm standard deviation ( $\mathrm{t}$ test).

${ }^{\mathrm{b}}$ Deaf and hard of hearing (DHH) individual.

${ }^{c}$ Always or frequently/rarely or never (a f/r $\mathrm{n}$ ).

ASL: Argentine Sign Language; PASLI: professional Argentine Sign Language interpreter;

OR: odds ratio; CI: confidence interval. 
recommendation of a PASLI. However, when the services of a PASLI were requested, the attempt was often unsuccessful and, therefore, nonprofessional interpreters were used, who may have not interpreted the information provided by a physician effectively.

There are no statistical data available to confirm the number of licensed PASLI in Argentina. Studies conducted in Spain have demonstrated that the number of available interpreters is not enough to meet the demand. ${ }^{13}$ Similarly, in Argentina, few provinces have PASLI education institutions. To solve this problem, an option may be to encourage PASLI education and certification at a national level.

This study was based on a sample of SAP members; therefore, it may be affected by a selection bias. Pediatricians who were invited to take the survey were informed about the purpose of knowing about the use of interpretation services among DHH individuals. Thus, the survey may have been completed mostly by pediatricians with experience in dealing with people with disabilities (as shown by the high percentage of pediatricians who had seen $\mathrm{DHH}$ patients), which would deem the results as reflecting a less serious situation than what it actually is.

The 381 pediatricians who completed the survey accounted for $13.4 \%$ of SAP members who practiced in CABA. Therefore, the response rate in this study was similar to that observed in studies that used a similar sampling methodology through the SAP's mailing list. ${ }^{15}$

According to our study, part of pediatricians who practiced in CABA had no knowledge of Act No. 26378 and did not routinely recommend a PASLI. It is necessary to raise awareness about the rights of people with disabilities among health care providers because they are essential social actors for the enforcement of currently valid legal regulations.

\section{CONCLUSIONS}

Only $15.1 \%$ of SAP member pediatricians who practice in CABA have knowledge of Act No. 26378. Having such knowledge was significantly associated with the recommendation of a PASLI during a medical consultation.

\section{REFERENCES}

1. GBD 2015 Disease and Injury Incidence and Prevalence Collaborators. Global, regional, and national incidence, prevalence, and years lived with disability for 310 diseases and injuries, 1990-2015: a systematic analysis for the Global Burden of Disease Study 2015. Lancet. 2016; 388(10053):1545-602.

2. World Health Organization. Deafness and Hearing Loss. Washington DC, 2020. [Accessed on: February 15 ${ }^{\text {th }}, 2018$ ]. Available at: https:/ / www.who.int/news-room/factsheets / detail/ deafness-and-hearing-loss.

3. Argentina. Ministerio de Salud. Audífonos e implantes cocleares gratuitos para promover la integración social de los niños sordos. 2012 [Accessed on: January $\left.24^{\text {th }}, 2018\right]$. Available at: http://www.msal.gob.ar/ prensa $/$ index.php?option $=$ com_content\&view $=$ articl e\&id=439:audifonos-e-implantes-cocleares-gratuitospara-promover-la-integracion-social-de-los-ninossordos\&catid=1:noticias439.

4. Emond A, Ridd M, Sutherland H, Allsop L, et al. The current health of the signing Deaf community in the UK compared with the general population: a cross-sectional study. BMJ Open. 2015; 5(1):e006668.

5. Woodcock K, Pole JD. Health profile of deaf Canadians: analysis of the Canada Community Health Survey. Can Fam Physician. 2007; 53(12):2140-1.

6. Barnett S, McKee M, Smith SR, Pearson TA. Deaf sign language users, health inequities, and public health: opportunity for social justice. Prev Chronic Dis. 2011; 8(2):A45.

7. Bat-Chava Y, Martin D, Kosciw JG. Barriers to HIV / AIDS knowledge and prevention among deaf and hard of hearing people. AIDS Care. 2005; 17(5):623-34.

8. Ley N. ${ }^{\circ}$ 27044. Jerarquía Constitucional. Convención sobre los derechos de las personas con discapacidad. Boletín Oficial de la República Argentina. Buenos Aires, 22 de diciembre de2014. [Accessed on: January $15^{\text {th }}$, 2018]. Available at: http://servicios.infoleg.gob.ar/ infolegInternet / verNorma.do?id=239860.

9. Convención sobre los Derechos del Niño. Buenos Aires, 27 de setiembre de 1990. [Accessed on: February 25 $5^{\text {th }}, 2018$ ]. Available at: https: / / www.oas.org/dil/esp/Convencion_ sobre_los_Derechos_del_Nino_Argentina.pdf.

10. Cutri AM, Torres FA, Riquelme CC, Cabrera NB, et al. Prevalencia de personas sordas que cuentan con un intérprete profesional de Lengua de Señas Argentina en la consulta médica de sus hijos. Arch Argent Pediatr. 2018; 116(5):310-5.

11. SurveyMonkey LLC.SurveyMonkey®. 2012. [Accessed on: October $\left.4^{\text {th }}, 2019\right]$. Available at: https: / / es.surveymonkey. com.

12. Willis GB. Cognitive Interviewing: A Tool for Improving Questionnaire Design. California: SAGE Publications, Inc; 2004.

13. Muñoz-Baell IM, Ruiz-Cantero MT, Alvarez-Dardet C, Ferreiro-Lago E, et al. Comunidades sordas: ¿pacientes o ciudadanas? Gac Sanit. 2011; 25(1):72-8.

14. Asch DA, JedrziewskiMK, Christakis NA. Response rates to mail surveys published in medical journals. JClin Epidemiol. 1997; 50(10):1129-36.

15. Goldfarb G, Nasanovsky J, Krynski L, Ciancaglini A, et al. Uso de tecnologías de la información y comunicación por pediatras. Arch Argent Pediatr. 2019; 117(6):S264-76. 


\section{ANNEX \\ Survey about Argentine Sign Language}

\section{Dear Doctor:}

The purpose of this survey is to assess to what extent pediatricians in Argentina are aware of the rights of Deaf people to have a professional Argentine Sign Language interpreter present during medical consultations. This information will be highly valuable for the promotion and design of actions aimed at improving patient-doctor communication.

Completing this questionnaire will take less than 5 minutes. Answers will remain confidential and no identifying information will be kept.

If you agree, please click ACCEPT to give your consent and begin the survey.

Thank you for your participation.

Subcommittee on the Rights of the Child, Sociedad Argentina de Pediatria

1. Are you a pediatrician? Yes/No.

2. Where do you practice as a pediatrician? [You may select more than one answer].

Autonomous City of Buenos Aires.

Other place:

3. How old are you? -

4. How long have you been a pediatrician (including your residency program/postgraduate attachment)?

5. What is your gender? Male/Female/Other/Prefer not to say.

6. In what setting do you work more hours?

Public institution/Private institution/Trade union health insurance institution.

7. Have you ever seen Deaf or hard of hearing patients or parents? [You may select more than one answer].

Yes, patients / Yes, parents / No, neither patients nor parents.

8. Do you have knowledge of Argentine Sign Language (ASL)? Yes/ No.

9. Have you ever tried to learn Argentine Sign Language (ASL)? Yes / No.

10. To what extent do you master Argentine Sign Language (ASL)? Very well/Well/ Not very well/Not at all.

11. Do you have any Deaf or hard of hearing family member or friend? Yes / No.

12. Approximately, how many Deaf or hard of hearing patients have you seen?

13. Approximately, how many patients whose parents were Deaf or hard of hearing have you seen?

14. How do you usually communicate with Deaf or hard of hearing patients or parents?

[You may select more than one answer].

I talk and they lipread/I use Argentine Sign Language/Through a professional Argentine Sign Language interpreter (PASLI)/ Through a non-professional interpreter (child, family member, friend, neighbor, etc.)/Written language.

15. Considering your knowledge of Argentine Sign Language (ASL), do you think communication between you and a Deaf or hard of hearing person would improve with the presence of a professional Argentine Sign Language interpreter (PASLI)? Yes/ No. 
16. How often is there someone who serves as an interpreter (professional or non-professional) between you and a Deaf or hard of hearing patient or parents? Always/Frequently / Rarely / Never.

17. When there is someone acting as an interpreter, how often is this person a professional Argentine Sign Language interpreter (PASLI)?

Always / Frequently/Rarely/Never.

18. When there is someone acting as an interpreter, how often is this person a non-professional interpreter (child, family member, friend, neighbor, etc.)?

Always / Frequently / Rarely / Never.

19. How often does a Deaf or hard of hearing patient or parent bring a professional interpreter (PASLI) to the visit on their own means?

Always / Frequently / Rarely/Never.

20. How often do you recommend using a professional interpreter (PASLI) to a Deaf or hard of hearing patient or parent when there is no interpreter present? Always / Frequently/Rarely / Never.

21. Why did you recommend using a professional interpreter (PASLI) in those cases? Please, describe it in your own words:

22. Why did you not recommend using a professional interpreter (PASLI) in those cases? [You may select more than one answer].

Because I was not aware of the profession/Because we were able to communicate well enough without a PASLI/Because I did not know the process to get a PASLI/Other (please, describe it in your own words):

23. How often did you recommend using a professional interpreter (PASLI) to a Deaf or hard of hearing patient or parent when there was a non-professional interpreter (child, family member, friend, neighbor, etc.) present? Always / Frequently / Rarely / Never.

24. Why did you recommend using a professional interpreter (PASLI) in those cases? Please, describe it in your own words:

25. Why did you not recommend using a professional interpreter (PASLI) in those cases? [You may select more than one answer]. Because I was not aware of the profession.

Because we were able to communicate well enough without a PASLI.

Because I did not know the process to get a PASLI.

Other (please, describe it in your own words):

26. Have you ever had any trouble trying to get the services of a professional interpreter (PASLI) after requesting one?

Yes (please, describe it in your own words): . No.

27. Have you ever tried to get the services of a non-professional interpreter after having trouble requesting a professional interpreter (PASLI)? Yes/No.

28. Do you have knowledge of the letter of Act no. 26378 (Convention on the Rights of Persons with Disabilities) in relation to Deaf or hard of hearing individuals? Yes/No.

29. Can you describe what Act No. 26378 says in relation to Deaf and hard of hearing individuals? Please, describe it in your own words: 